\title{
Correlation Between Constitutional Changes and Development Paradigm on Regional Development Planning
}

\author{
Titut Amalia ${ }^{1, *}$, Yos Johan Utama ${ }^{2}$ and Ani Purwanti ${ }^{3}$ \\ ${ }^{1}$ Faculty of Law, Diponegoro University, Semarang, Indonesia \\ ${ }^{2}$ Faculty of Law, Diponegoro University, Semarang, Indonesia \\ ${ }^{3}$ Faculty of Law, Diponegoro University, Semarang, Indonesia
}

\begin{abstract}
Indonesia's development planning cannot be separated from the underlying constitution. The 1945 Constitution as the constitution of the Indonesian nation experienced ups and downs with the occurrence of constitutional changes in the past several eras. Therefore, it is necessary to know how the correlation between changes in the Constitution to development planning in the region. Through qualitative research with this normative approach, it is known that changes in the development paradigm have more influence on changes in regional development planning when compared to changes that occur in the constitution. Therefore, the selection of the Development Paradigm that is used needs to be ensured that it does not deviate and is in accordance with the guiding values and principles of development namely the values of Pancasila contained in the 1945 Constitution.
\end{abstract}

\section{Introduction}

After the Proclamation of Independence on August 17, 1945 Indonesia laid the foundation of the ideals of the state formation in the Preamble of the 1945 Constitution which affirmed that the Indonesian State Government is formed to protect the entire Indonesian nation and all the Indonesian bloodshed and to advance the general welfare, to educate the nation's life, and to participate in carrying out the world order based on independence, lasting peace and social justice [1]. Therefore development must, in fact, be carried out while ensuring that the intended objectives can be achieved with the availability of available resources. Thus, the development planning is important to do. Development planning in general according to Sjafrizal, is a way or technique to achieve development goals appropriately, directed, and efficiency in accordance with the conditions of the country or region concerned [2].

Indonesia's development planning cannot be separated from the underlying constitution. Mustopadidjaja revealed that every government runs the wheels of development according

*Corresponding author: titutamalia@yahoo.com 
to Pancasila and the 1945 Constitution, but with a different choice of development paradigm [3]. The 1945 Constitution as the constitution of the Indonesian nation experienced ups and downs with the occurrence of constitutional changes in the past several eras. The 1945 Constitution as the Indonesian National Constitution was replaced by the 1949 Constitution of the Republic of Indonesia (The 1949 RIS Constitution) to The 1950 Provisional Constitution. The substitution of the Constitution should have an impact on the development planning. Therefore, the problem in this study is how the correlation between changes in the Constitution that occur in Indonesia and the impact on development planning in the region is. This research will also examine changes in the development paradigm of regional development planning.

\section{Objective of The Study}

This study examines the impact of changes in substance that occurred in the 1945 Constitution as the Indonesian constitution on regional development planning. It will also provide information on matters that affect development planning in the regions relevant to the substitution of the Constitution.

\section{Methodology}

This research is a qualitative research with a normative approach. This study uses secondary data in the form of legal materials to be reviewed and analyzed [4] which include Primary, Secondary and Tertiary Legal Materials. A review of several development planning regulations, the literature related to the development planning and the history of several Institutions will help in reviewing these changes and their impact.

\section{Discussion}

\subsection{Changes to the Constitution and Development Paradigm}

Law according to Mochtar Kusumaatmaja in the Theory of Development Law has some functions which one of them is as a means of development [5]. Therefore, after the Proclamation of August 17, 1945 Indonesia established and chose Pancasila as the philosophy basic of the Republic of Indonesia which is stated in the Preamble to the 1945 Constitution [6]. Pancasila as a state philosophy is inherent and animates the entire Preambule of the 1945 Constitution. Pancasila is constitutionally a guide in community life, nation and state. Thus, Pancasila is expected to play a role as a guide to the values and principles in choosing a paradigm, designing strategies and developing systems, processes as well as indicators of state performance and national development which will be set forth in the legislation below [3].

Political developments that were still unstable at the beginning of independence led to changes in the Indonesian Constitution. These changes have an impact on development planning. This can be seen in the following table: 
Tabel 1. Constitutional Development and Development Planning Documents (1945 - 2010)

\begin{tabular}{|c|c|c|c|}
\hline Constitution & $\begin{array}{l}\text { Legal Basic of } \\
\text { Planning } \\
\text { Development } \\
\end{array}$ & $\begin{array}{c}\text { Time of } \\
\text { Plannning }\end{array}$ & Planning Document \\
\hline $\begin{array}{l}\text { - The } 1945 \\
\text { Constitution } \\
\text { - The } 1949 \\
\text { RIS } \\
\text { Constitution } \\
\text { - }\end{array}$ & $\begin{array}{lr}\text { Government } & \\
\text { Declaration on } & \text { State } \\
\text { Development } & 18 \\
\text { August } 1945 & \end{array}$ & $\begin{array}{l}1947, \\
1948, \\
1949,1950\end{array}$ & $\begin{array}{l}\text { 1. Basics of Principles Instead of } \\
\text { Plans to Manage the Indonesian } \\
\text { Economy; } \\
\text { 2. Three-Year Production Plan, } 1948 \\
\text { - } 1950 \text { (Plan Kasimo) results of } \\
\text { the Ministry of Prosperity's } \\
\text { planning unit. }\end{array}$ \\
\hline $\begin{array}{l}\text { The } 1950 \\
\text { Provisional } \\
\text { Constitution }\end{array}$ & $\begin{array}{l}\text { Article } 52 \text { paragraph } \\
\text { (1) of the Provisional } \\
\text { Constitution } 1950\end{array}$ & $\begin{array}{l}\text { 1951-955, } \\
1956-1960\end{array}$ & $\begin{array}{l}\text { 1. Industrial Urgency Plan (RUI), } \\
1951 \text { - } 1953 \text {, extended to } 1955 . \\
\text { Results of the Industrialization } \\
\text { Committee of the Ministry of } \\
\text { Trade and Industry } \\
\text { 2. Five-Year Development Plan } \\
\text { (RPLT) } 1956-1960 \text {. }\end{array}$ \\
\hline \multirow[t]{5}{*}{$\begin{array}{l}\text { The } 1945 \\
\text { Constitution }\end{array}$} & $\begin{array}{l}\text { MPRS Decree No. } \\
\text { 1/MPRS/1960 } \\
\text { concerning the } \\
\text { Political Manifesto of } \\
\text { the Republic of } \\
\text { Indonesia as Outlines } \\
\text { rather than State } \\
\text { Policy. }\end{array}$ & $1961-1963$ & $\begin{array}{l}\text { The Eight Year Long Term } \\
\text { Development Plan is called the First } \\
\text { Phase of the National Planning } \\
\text { National and Development Plan } \\
\text { (RPNSB-I) 1961-1969 }\end{array}$ \\
\hline & $\begin{array}{l}\text { MPRS Decree No.IV } \\
\text { of } 1963 \text { concerning } \\
\text { Guidelines for } \\
\text { Implementation of } \\
\text { Lines - Outline of } \\
\text { State Guidelines and } \\
\text { Development } \\
\text { Guidelines }\end{array}$ & $1963-1969$ & $\begin{array}{l}\text { RPNSB 1961-1969 which was refined } \\
\text { or called the Struggle Economic Plan }\end{array}$ \\
\hline & $\begin{array}{l}\text { Cabinet Presidium } \\
\text { Instruction Number } \\
15 / \text { EK/IN/3/1967 of } \\
1967 \text { concerning the } \\
\text { Assignment of } \\
\text { Bappenas to draft five } \\
\text { development plans } \\
\text { from 1967-1973 }\end{array}$ & $1969-1973$ & $\begin{array}{l}\text { 1. Five-Year First Development Plan } \\
\text { (Repelita I) } 1969-1973 \text {. } \\
\text { 2. Plan for the State Budget } \\
\text { (RAPBN) of } 1969-1974 \text {. }\end{array}$ \\
\hline & $\begin{array}{l}\text { MPR Decree No. } \\
\text { IV/MPR/1973 } \\
\text { concerning GBHN }\end{array}$ & $\begin{array}{l}1974 / 1975 \\
- \\
1978 / 1979\end{array}$ & $\begin{array}{l}\text { 1. Repelita II } 1974-1979 . \\
\text { 2. RAPBN 1974-1979. }\end{array}$ \\
\hline & $\begin{array}{l}\text { MPR Decree No. } \\
\text { IV/MPR/1978 } \\
\text { concerning GBHN. }\end{array}$ & $\begin{array}{l}1979 / 1980 \\
- \\
1983 / 1984 \\
\end{array}$ & $\begin{array}{l}\text { 1. Repelita III 1979-1984. } \\
\text { 2. RAPBN 1979-1984. }\end{array}$ \\
\hline
\end{tabular}




\begin{tabular}{|c|c|c|c|}
\hline Constitution & $\begin{array}{l}\text { Legal Basic of } \\
\text { Planning } \\
\text { Development }\end{array}$ & $\begin{array}{c}\text { Time of } \\
\text { Plannning }\end{array}$ & Planning Document \\
\hline & $\begin{array}{l}\text { MPR Decree No. } \\
\text { II/MPR/1983 } \\
\text { concerning GBHN. }\end{array}$ & $\begin{array}{l}1984 / 1985 \\
- \\
1988 / 1989 \\
\end{array}$ & $\begin{array}{l}\text { 1. Repelita IV } 1984-1989 . \\
\text { 2. RAPBN of 1984-1989. }\end{array}$ \\
\hline & $\begin{array}{l}\text { MPR Decree No. } \\
\text { II/MPR/1988 } \\
\text { concerning GBHN } \\
\end{array}$ & $\begin{array}{l}1989 / 1990 \\
- \\
1993 / 1994 \\
\end{array}$ & $\begin{array}{l}\text { 1. Repelita V 1989- } 1994 . \\
\text { 2. RAPBN 1989-1994. }\end{array}$ \\
\hline & $\begin{array}{l}\text { MPR Decree No.II/ } \\
\text { MPR/1993 } \\
\text { concerning GBHN. }\end{array}$ & $\begin{array}{l}1994 / 1995 \\
- \\
1998 / 1999 \\
\end{array}$ & $\begin{array}{ll}\text { 1. Repelita VI } 1994-1999 . \\
\text { 2. RAPBN of 1994-1999. }\end{array}$ \\
\hline & $\begin{array}{l}\text { MPR Decree No. } \\
\text { IX/MPR/1998 } \\
\text { concerning } \\
\text { Principles the } \\
\text { Development Reform } \\
\text { in the Context of } \\
\text { Rescue } \\
\text { Normalization and } \\
\text { National Life as State } \\
\text { Policy. }\end{array}$ & 1998-1999 & $\begin{array}{l}\text { 1. National Development } \quad \text { Plan } \\
\text { (Transition) } 1999-2000 .\end{array}$ \\
\hline \multirow[t]{4}{*}{$\begin{array}{l}\text { The } 1945 \\
\text { Constitution of } \\
\text { the Republic of } \\
\text { Indonesia }\end{array}$} & $\begin{array}{l}\text { MPR Decree No. } \\
\text { IV/MPR/1999 } \\
\text { concerning GBHN. }\end{array}$ & 2000-2004 & $\begin{array}{l}\text { 1. } \begin{array}{l}\text { National Development } \\
\text { (Propenas) } 2000-2004 .\end{array} \\
\text { 2. Annual Development } \\
\text { (Repeta) 2000- 2004. }\end{array}$ \\
\hline & $\begin{array}{l}\text { The Chosen Vision } \\
\text { and Mission of the } \\
\text { President. }\end{array}$ & 2004-2009 & $\begin{array}{lll}\text { 1. } & \text { National Long Term } \\
\text { Development Plan (RPJMN) } 2004 \\
\text {-4009. } \\
\text { 2. } \\
\text { Government Work Plans (RKP) } \\
\text { 2005-2009. }\end{array}$ \\
\hline & $\begin{array}{l}\text { Republic of Indonesia } \\
\text { Law Number } 25 \text { Year } \\
2004 \text { concerning the } \\
\text { National } \\
\text { Development } \\
\text { Planning System. }\end{array}$ & $2005-2025$ & $\begin{array}{l}\text { Law Number } 17 \text { Year } 2007 \text { on } \\
\text { National Long Term Development } \\
\text { Plan (RPJMN) } 2005-2025 .\end{array}$ \\
\hline & $\begin{array}{l}\text { National Long Term } \\
\text { Development Plan } \\
\text { (RPJPN) 2005 - 2025, } \\
\text { Elected President's } \\
\text { Vision and Mission. }\end{array}$ & $2010-2014$ & $\begin{array}{l}\text { 1. RPJMN } 2010-2014 . \\
\text { 2. RKP 2010- } 2014 .\end{array}$ \\
\hline
\end{tabular}

Source: [3]

The development of the Development Paradigm which lasted from 1945 to 2015 is as follows:

a. 1945-1949

Collectivity in the administration of the state and nation-building, enhance the ability of individuals and communities to maintain and fill independence and the spirit of cooperation in realizing a just and prosperous society according to the constitution. 
b. $1950-1959$.

Independence and anti-independence with the mindset of freedom of association and assembly in the political, economic and social fields attempts to free themselves from dependence and poverty due to colonial domination. Development planning in this era is implementing a political economy system based on nationalism.

c. $1960-1965$

The National Planning National Development Plan (RPNSB) 1961-1969 was the Political Manifesto (Manipol) of the Republic of Indonesia and the 1945 Constitution, Indonesian Socialism, Guided Democracy, Guided Economy, and Indonesian Personality (Manipol - Usdek) National, Religion, Communist (Nasakom ).

d. $1966-1998$

The constitutional and rational arrangement of the political and economic system is based on the spirit of returning to Pancasila and the 1945 Constitution purely and consistently. Economic and political policies reflect the articles in the 1945 Constitution based on economic democracy and controlled by market mechanisms. The pattern of governance and development at that time was a five-year national leadership cycle and a "development trilogy" that combined healthy and dynamic growth, equity and national stability, accompanied by improvements in the quality of Human Resources, human development, sustainable development.

e. $1998-2004$

Total planned, institutionalized and sustainable reforms to improve all deviations in the economic, political and governmental institutions along with efforts to realize autonomy (decentralization) and the principle of "good and clean governance".

f. 2004-2015

Development strategy for the United Indonesia Cabinet I, is "pro-growth, pro poor, pro jobs" and quality development ". The development paradigm of the United Indonesia Cabinet II is a balanced, inclusive and creative development towards a prosperous, democratic and just Indonesia [3].

The above conditions explain that Indonesia has experienced several constitutional changes due to the development of the conditions and dynamics of the life of the Indonesian people. In the phase of constitutional change there was also a change in the Development Paradigm and those that did not result in changes to the development paradigm.

\subsection{Impact of Constitutional Change and Development Paradigm on Regional Development Planning}

The purpose of regional development according to Ginandjar Kartasasmita is to improve the standard of living and welfare of the people in the region through harmonious and integrated development between sectors and sectors with efficient and effective regional development planning for regional independence and equitable progress in all corners of the country [7]. Therefore development planning plays an important role in creating effective and efficient development. The following is the relevance between constitutional changes, the choice of development paradigm for regional development planning:

a. Changes to the 1945 Constitution became The 1949 RIS Constitution.

Early independence of development planning was carried out based on the 1945 Constitution. Changes to the 1949 RIS Constitution of the United States of Indonesia (RIS) did not cause significant changes because the substance of the foundation of development planning which is still the same is contained in the 1945 Constitution contained in the 1949 RIS Constitution[3]. 
b. Changes to The 1949 RIS Constitution became The 1950 Provisional Constitution.

The implementation of the 1949 RIS Constitution in a short time, resulting in changes in that period did not have a significant impact on regional development planning. This is also due to the absence of substantial changes in the contents of the constitution. According to Prof. Soepomo, the philosophy of the state and the implementation of development used in the 1949 RIS Constitution, the 1950 Provisional Constitution (UUDS) and the 1945 Constitution were Pancasila. The similarity is also found in the substance of the philosophy of development Article 38 of the 1950 Provisional Constitution and Article 33 of the Constitution of 1945. The development paradigm in the 1950-1995 eras was an antidependence paradigm that resulted in science-based development planning [3].

c. Changes to the 1950 Provisional Constitution became The 1945 Constitution.

Reusing the 1945 Constitution caused by the failure to draft a new constitution through the Presidential Decree of July 5, 1959, has the addition of the Republic of Indonesia's Political Manifesto (Manipol) and the 1945 Constitution, Indonesian Socialism, Guided Democracy, Guided Economy and Indonesian Personality designated as Lines - Outline of the State Policy through the Decree of the Republic of Indonesia MPRS Number 1 / MPRS / 1960. This condition shows a change in the development paradigm from Liberal to Guided [3].

During this period the National Development Planning Agency (Bappenas) was formed, the Department of Planning and Research (Bapperdep) and the Regional Development Coordination Agency (Bakopda) [3]. The development planning process continues to experience improvements and has an impact on regional development planning. The importance of bottom-up and top-down development planning development is important so that the Minister of Home Affairs Regulation No. 9 Year 1982 concerning Guidelines for the Preparation of Regional Development Planning and Control (P5D) is established. Based on the Minister of Home Affairs Regulation, planning documents include:

1. Long-term Development Planning Documents, namely the Provincial Basic Development Pattern (Poldas) and District Development Patterns (Poldas) which are guided by the Outline - State Policy Outline and implemented according to the conditions, and potential of the region according to their level.

2. Medium-Term Regional Development Planning Document, namely the Five-Year Regional Development Plan (Repelitada)/Regional Development Program (Propeda) consisting of the Provincial Repelitada / Propeda and the District Repelitada / Propeda.

3. Short-term Regional Development Planning Documents namely the Regional Annual Development Plan (Repetada) consisting of Provincial and District levels[8].

d. Changes to The 1945 Constitution became the 1945 Constitution of the Republic of Indonesia.

The 1998 Reformation encouraged an amendment of 4 (four) times to the 1945 Constitution. The fundamental changes that impacted changes in development planning were Articles 18, 18 A and 18 B of the 1945 Constitution of the Republic of Indonesia which affirmed the provision of wider autonomy to the Regional Government[3]. The amendment encouraged the birth of Law Number 25 Year 2004 concerning the National Development Planning System which regulates the substance and procedures for the progress of development planning both at the central and regional levels. This was also followed by the birth of Law Number 32 Year 2004 concerning Regional Government. Then the Minister of Home Affairs Regulation Number 54 Year 2010 which has now been replaced by the Minister of Home Affairs Regulation Number 86 Year 2017 concerning Procedures for Planning, Regional Development Control and Evaluation, Procedures for Evaluating Regional Regulation Draft on Regional Long Term Development Plans and Regional Medium Term Development Plans, and Procedures for Changing Regional Long Term Development Plans, Regional Medium Term Development Plans, and Government Work Plans Area. The replacement was due to the birth of Law Number 23 Year 2014 concerning 
Regional Government. These laws and regulations regulate the substance and procedure of development planning in the region. Participatory development planning is increasingly developed in addition to top down and bottom up in order to strengthen the process of delivering aspirations in the regional development planning process.

Based on the above conditions, changes in development planning can occur if there is a change in the development paradigm and substantive changes in the Constitution. If there is no substantive change in the Constitution, it will not affect development planning. Changes in the development paradigm do not always follow or are followed by changes in the Constitution. So that the development paradigm has more influence on development planning. The fact shows that the development paradigm is sometimes not relevant/not related to the existence of the constitution. Sorting the development paradigm sometimes does not pay attention to the values contained and agreed upon in the constitution. This certainly needs to be a concern given the use of the development paradigm will have an impact on the laws and regulations of development planning and the results of development both at the central and regional levels. Sorting, choosing and using development paradigms need to be considered in order to remain in accordance with the conditions and national identity that is in accordance with the values of Pancasila contained in the 1945 Constitution.

\section{Conclusion}

Constitutional changes in Indonesia can have an impact on regional development planning in Indonesia if there is a change in substance in it. However, the change in the development paradigm has more influence on changes in development planning when compared to changes that occur in the constitution. Therefore the selection of the Development Paradigm that is used needs to be ensured that it does not deviate and is in accordance with the guiding values and principles of development namely the values of Pancasila contained in the 1945 Constitution.

\section{References}

1. H. Alrasid, Naskah UUD 1945 Sesudah Empat Kali Diubah oleh MPR (Penerbit Universitas Indonesia, Jakarta, 2003)

2. Sjafrizal, Perencanaan Pembangunan Daerah Dalam Era Otonomi (Rajawali Pers, Jakarta, 2016)

3. A. R. Mustopadidjaja, et.al editor, Bappenas Dalam Sejarah Perencanaan Pembangunan Indonesia 1945 - 2025 (LP3ES, Jakarta, 2012)

4. S. Soekanto, Pengantar Penelitian Hukum (Penerbit Universitas Indonesia, Jakarta, 1984)

5. Sidharta dkk, Mochtar Kusumaatmadja Dan Teori Hukum Pembangunan Eksistensi dan Implikasi (Epistema Institute, Jakarta, 2012)

6. Kaelan, Pendidikan Pancasila (Penerbit Paradigma, Yogyakarta, 2016)

7. G. Kartasasmita, Pembangunan Untuk Rakyat Memadukan Pertumbuhan dan Pemerataan (Cides, Jakarta, 1996)

8. Regulation of Ministry of Home Affair Number 9 year 1982 concerning Guidelines for Preparing Regional Development Planning and Control 